\title{
1 Changes in nutrient concentrations of leaves and roots in 2 response to Global Change factors.
}

3

4

5

6 \section{列}

JORDI SARDANS ${ }^{2}$, ORIOL GRAU ${ }^{1,2}$, HAN Y. H. CHEN ${ }^{3}$, IVAN A. JANSSENS ${ }^{4}$, PHILIPPE CIAIS $^{5}$, SHILONG PIAO ${ }^{6}$, JOSEP PEÑUELAS ${ }^{1,2}$

(1)

${ }^{1}$ CSIC, Global Ecology Unit CREAF-CEAB-UAB, Cerdanyola del Vallès, 08193 Catalonia, Spain. 2 CREAF, Cerdanyola del Valles, 08193 Catalonia, Spain.

${ }^{3}$ Faculty of Natural Resources Management, Lakehead University, 955 Oliver Road, Thunder Bay, Ontario, P7G 1A6, Canada.

${ }^{4}$ Research Group of Plant and Vegetation Ecology (PLECO), Department of Biology, University of Antwerp, B-2610 Wilrijk, Belgium.

${ }^{5}$ Laboratoire des Sciences du Climat et de l'Environnement, IPSL, 91191 Gif-sur-Yvette, France.

${ }^{6}$ Sino-French Institute for Earth System Science, College of Urban and Environmental Sciences, Peking University, Beijing 100871, China.

Running head: Foliar and root nutrients under global change

7

This is the accepted version of the following article: Sardans, J. et al. "Changes in nutrient concentrations of leaves and roots in response to global change factors" in Global change biology,vol. 23, issue 9 (Sep. 2017), p. 3849-3856, which has been published in final form at DOI $10.1111 / \mathrm{gcb} .13721$. This article may be used for non-commercial purposes in accordance with Wiley Terms and Conditions for Self-Archiving." 


\section{Abstract}

33 Global Change impacts on biogeochemical cycles have been widely studied, but our understanding of whether the responses of plant elemental composition to Global Change

8 drivers differ between above- and belowground plant organs remains incomplete. We conducted a meta-analysis of 201 reports including 1,687 observations of studies that have analyzed simultaneously $\mathrm{N}$ and $\mathrm{P}$ concentrations changes in leaves and roots in the same plants in response to drought, elevated $\left[\mathrm{CO}_{2}\right]$, and $\mathrm{N}$ and $\mathrm{P}$ fertilization around the world, and contrasted the results within those obtained with a general database (838 reports and 14,772 observations) that analyzed the changes in $\mathrm{N}$ and $\mathrm{P}$ concentrations in leaves and/or roots of plants submitted to the commented global change drivers. At global level, elevated $\left[\mathrm{CO}_{2}\right]$ decreased $\mathrm{N}$ concentrations in leaves and roots and decreased $\mathrm{N}: \mathrm{P}$ ratio in roots but no in leaves, but was not related with $\mathrm{P}$ concentration changes. However, the response differed among vegetation types. In temperate forests elevated $\left[\mathrm{CO}_{2}\right]$ was related with lower $\mathrm{N}$ concentrations in leaves but not in roots, whereas in crops the contrary patterns were observed. Elevated $\left[\mathrm{CO}_{2}\right]$ decreased $\mathrm{N}$ concentrations in leaves and roots in tundra plants, whereas not clear relationships were observed in temperate grasslands. However, when elevated $\left[\mathrm{CO}_{2}\right]$ and $\mathrm{N}$ fertilization coincided, leaves had lower $\mathrm{N}$ concentrations whereas root had higher $\mathrm{N}$ concentrations suggesting that more nutrients will be allocated to roots to improve uptake of the soil resources not directly provided by the global change drivers. $\mathrm{N}$ fertilization and drought increased foliar and root $\mathrm{N}$ concentrations while the effects on $\mathrm{P}$ concentrations were less clear. The changes in $\mathrm{N}$ and $\mathrm{P}$ allocation to leaves and root, especially those occurring in opposite direction between them have the capacity to differentially affect above- and below-ground ecosystem functions, such as litter mineralization and above- and belowground food webs.

Keywords. $\mathrm{CO}_{2}$; ecological stoichiometry; drought, $\mathrm{N}$ deposition; nitrogen; $\mathrm{N}: \mathrm{P}$; phosphorus. 
Introduction

Global Change is characterized by simultaneous shifts in multiple factors that affect ecosystem functioning, such as elevated $\left[\mathrm{CO}_{2}\right], \mathrm{N}$ deposition, warming and drought, species invasion, and many others (Elser et al., 2010; Sardans et al., 2012; Peñuelas et al., 2013). Several of these Global Change drivers are known to affect nutrient cycling and availability. Several interactions among drivers of Global Change, such as elevated $\mathrm{CO}_{2}$ concentrations, $\mathrm{N}$ and $\mathrm{P}$ fertilization, drought or species invasion, with ecosystemic nutrient availability and cycles have been reported (Sardans \& Peñuelas, 2012). A recent meta-analysis by Yuan and Chen (2015) reported different shifts in whole-plant $\mathrm{N}$ and $\mathrm{P}$ concentrations and in $\mathrm{C}: \mathrm{P}, \mathrm{C}: \mathrm{N}$ and $\mathrm{N}: \mathrm{P}$ ratios in response to elevated $\left[\mathrm{CO}_{2}\right], \mathrm{N}$ and $\mathrm{P}$ fertilization, drought and warming, consistent with previous studies (Sardans et al., 2008; Duval et al., 2012). Another recent meta-analysis (Deng et al., 2015) reported decreases in plant $\mathrm{N}$ and $\mathrm{P}$ concentrations and $\mathrm{N}: \mathrm{P}$ ratios under elevated $\left[\mathrm{CO}_{2}\right]$. Foliar nutrient concentrations correlate with overall shifts in plant and ecosystemic functioning (Kerkhoff et al., 2005; Kerkhoff \& Enquist, 2006), so the results of these meta-analyses have motivated modelers to include $\mathrm{N}$, and more recently $\mathrm{P}$ controls on photosynthesis and plant growth for projecting the future evolution of carbon sinks (Peñuelas et al., 2013; Van der Velde et al., 2014).

Changes in nutrient use and allocation in response to changes in environmental conditions are likely to vary among plant organs as a consequence of their particular functions. Recent studies by Gargallo-Garriga et al. $(2014,2015)$ have observed different metabolic and nutrient responses in photosynthetic tissues and roots in different grasses submitted to distinct levels of drought and warming. Root metabolism under drought shifted toward the up-regulation of primary metabolism linked with growth and energy 
production, whereas photosynthetic tissues in the same plants shifted toward the upregulation of secondary metabolism associated with anti-stress and conservative functions and toward the down-regulation of primary metabolism (growth and energy production). These asymmetrical effects on metabolic function between photosynthetic organs and roots of the same plants were also correlated with asymmetrical allocations of $\mathrm{N}$ and $\mathrm{P}$ to photosynthetic organs and roots, with more nutrients to roots to allow that up-regulation and less to leaves related to the observed down-regulation (Gargallo-Garriga et al., 2014, 2015).. Interactions between different drivers such as $\mathrm{CO}_{2}$ and nutrient fertilization introduce further complexity, because their effects can be synergistic or antagonistic, and not simply additive (Churkina et al., 2009; Leuzinger et al., 2011; Dieleman et al., 2012; Reich \& Hobbie, 2012; Thomas et al., 2013). Meyerholt \& Zaehle (2015) reported that a model of forest production consistently produced the best results when changes in the C:N ratio were decoupled among different plant organs Thus, the possible different relationships of global change drivers with distinct plant organs warrant investigation. Despite previous studies have demonstrated general effects of global change drivers such as elevated $\left[\mathrm{CO}_{2}\right]$, drought, warming, $\mathrm{N}$ and $\mathrm{P}$ fertilization and species invasion on plant $\mathrm{N}$ and P concentrations and N:P ratios (Yuan and Chen, 2015; Deng et al., 2015; Sardans et al., 2017), these studies have not distinguished among plant organs and have mainly focused on aboveground data, so a clear understanding of whether the effects of global change drivers are different in distinct plant organs, issues that can only be determined by using studies that provided simultaneous data for the different plant organs of the same plants submitted to different environmental conditions.

All these empirical data illustrate the need to account separately for nutrient adjustments in different plant organs to better understand carbon and nutrient cycles. Several experiments have observed different responses to elevated $\mathrm{CO}_{2}$ of both $\mathrm{N}(\mathrm{Li}$ et 
111 al., 2013; Liu et al., 2013a) and P (Duval et al., 2012; Li et al., 2013; Liu et al., 2013b)

112 concentrations in different plant organs. In situ climate manipulation experiments have also 113 revealed asymmetrical relationships of warming and/or drought, with contrasting changes 114 in N (Sardans et al., 2008a; Akmal et al., 2010) and P (Sardans et al., 2008b) 115 concentrations among different plant organs. These asymmetrical relationships between 116 leaves and roots have been observed not only for $\mathrm{N}$ and $\mathrm{P}$ but also for other elements 117 (Gargallo-Garriga et al., 2014, 2015). The response of the elemental compositions of 118 leaves and roots to environmental changes, hereafter elevated $\left[\mathrm{CO}_{2}\right], \mathrm{N}$ and $\mathrm{P}$ fertilization 119 and drought, however, has not yet been analyzed globally and for different vegetation 120 types. Such global analysis of plant leaves and roots is crucial to project global change 121 impacts on the functional composition of plant communities, plant-microbe-soil interactions 122 and possible mismatches between aboveground versus belowground processes.

We hypothesized that the impacts of Global-Change drivers on plant elemental 124 composition differ between leaves and roots due to their different functions. We 125 hypothesize that more nutrients will be allocated to roots to improve uptake of the 126 resources not provided by the global change drivers. For example, more nutrients should 127 be allocated to roots under drought, to enhance root primary metabolism and growth for

128 uptake of soil water. To test this hypothesis, we conducted a global meta-analysis of 129 published data on the response of nutrient concentrations in foliar and root tissues of 130 different vegetation types elevated $\left[\mathrm{CO}_{2}\right], \mathrm{N}$ and $\mathrm{P}$ fertilization and drought and their 131 interactions.

\section{Material and Methods}

133 Data collection

134 We searched the ISI Web of Science using combinations of the following keywords: 135 availability, carbon, concentration, content, C:N, C:P, deposition, foliar, $\mathrm{CO}_{2}$, leaf, needle, 
136

137

138 139

140

141

142

143

144

145

146

147

148

149

150

151

152

153

154

155

156

157

158

159

160

161

nitrogen, $\mathrm{N}: \mathrm{K}, \mathrm{N}: \mathrm{P}$, phosphorus, plant, potassium, $\mathrm{P}: \mathrm{K}$, ratio, root, soil, solution, stoichiometric and stoichiometry. We obtained 838 reports with 14, 772 observations from around the world (see Figures 1-3, S1, S3-S5 ; Table S1, Supplementary Material).

\section{Data analyses}

We examined the effects of Global-Change drivers on the differences of foliar and root elemental compositions and stoichiometries between control and treated plants by calculating the response ratios from each study, as described by Hedges et al. (Hedges et al., 1999). The natural-log response ratio $(\ln R R)$ was calculated as $\ln \left(X_{i} / X_{n}\right)=\ln X_{i}-\ln X_{n}$, where $X_{i}$ and $X_{n}$ are the values of each observation in the treated and control plants, respectively. The sampling variance for each $\ln R R$ was calculated as $\ln \left[\left(1 / n_{\mathrm{i}}\right) \times\left(S_{\mathrm{i}} / X_{\mathrm{i}}\right)^{2}+\right.$ $\left.\left(1 / n_{\mathrm{n}}\right) \times\left(S_{\mathrm{n}} / X_{\mathrm{n}}\right)^{2}\right]$ using the R package metafor 1.9-2 (Viechtbauer, 2012), where $n_{\mathrm{i}}$ and $n_{\mathrm{n}}$, $S_{i}$ and $S_{n}$ and $X_{i}$ and $X_{n}$ are the treated and control sample sizes, standard deviations and mean response values, respectively. The natural-log response ratios were determined by specifying studies as random factors using the rma model in metafor. The difference in the $\mathrm{N}$ and $\mathrm{P}$ concentrations and $\mathrm{N}: \mathrm{P}$ ratios between the leaves and roots of treated and control plants were considered significant if the $95 \%$ confidence interval of $\ln R R$ did not overlap zero. All statistical analyses were performed in RStudio 3.1.2 (R Core team, 2015). We analyzed only the variables with more than 30 observations available at the Global scale. We thereafter examined the sensitivities of plant nutrient concentrations and their stoichiometries to the Global-change drivers using REML estimation in the rma.unl model for metafor. We defined sensitivity as the change of the variable ( $\mathrm{N}$ and $\mathrm{P}$ concentrations, in $\mathrm{mg} \mathrm{g}^{-1}$, and $\mathrm{N}: \mathrm{P}$ ratios in roots and leaves) as a function of the unit of the Global-Change driver, i.e. $\mathrm{ppm} \mathrm{CO}_{2}$ for elevated $\left[\mathrm{CO}_{2}\right], \mathrm{kg} \mathrm{ha}^{-1}$ for $\mathrm{N}$ and $\mathrm{P}$ fertilization and $\mathrm{I} \mathrm{m}^{-2}$ of rainfall for drought. To avoid the possible bias we have focused on the meta-analyses of the studies that simultaneously analyzed leaves and roots of the same plants. We have also 
162 analyzed data from the studies that analyzed leaves and roots of the same plants or 163 different plants to only confirm the results (results provided in supplementary material). 164 The number of reports and observations used for the statistical analysis of each foliar and 165 root variable studied are shown in Figures 1-3. The equivalent meta-analysis on global 166 data set with all reports with information on leaf and/or roots was also shown (Figures S1167 S6, Supplementary Material). We also analyzed the natural-log response ratio of different 168 biomes when possible (more than 15 different observations). 


\section{Results}

General stoichiometric responses of leaves and roots

193 Studies providing data for leaves and roots of the same plants showed that elevated $\left[\mathrm{CO}_{2}\right]$ 194 is associated with decreases in both foliar and root $\mathrm{N}$ concentrations (Figure 1; Table 1). 195 The natural-log response ratios (from here onward simplified as response ratios) of $\mathrm{N}$ 196 concentrations was thus negative in leaves and roots associated to elevated $\left[\mathrm{CO}_{2}\right]$, 197 whereas no effect was observed for foliar and root $P$ concentrations (Figure 1) With 198 drought, both leaf and root $\mathrm{N}$ concentrations increased, root $\mathrm{P}$ increased marginally $199(P<0.1)$, whereas leaf $\mathrm{P}$ did not change (Figure 1). $\mathrm{N}$ fertilization increased $\mathrm{N}$ 200 concentrations in both leaves and roots and decreased in P concentrations in roots (Figure 201 1). These changes translated into increases in the leaf and root $N: P$ ratio under drought 202 (Figure 1). The combination of elevated $\left[\mathrm{CO}_{2}\right]$ and $\mathrm{N}$ fertilization was related with an increase 204 of root $\mathrm{N}$ and $\mathrm{P}$ concentrations and also a decrease in leaf $\mathrm{N}$ concentrations (Figure 1). 205 Fertilization with both $\mathrm{N}$ and $\mathrm{P}$ increased both foliar and root $\mathrm{N}$ and $\mathrm{P}$ concentrations 206 (Figure 1). Table 1 summarizes these results from studies where leaves and roots were 207 simultaneously measured.

208 Studies providing all available data, including also root-only or foliage-only 209 responses from different experiments, reported similar results (Figure S1). There were 210 similar responses of $\mathrm{N}$ and $\mathrm{P}$ concentrations to elevated $\left[\mathrm{CO}_{2}\right]$ (Figures S1). Leaves had 211 lower $\mathrm{N}: \mathrm{P}$ ratio under elevated $\left[\mathrm{CO}_{2}\right]$, whereas no effects were observed in roots (Figure 212 S1). Drought was associated with higher $\mathrm{N}$ concentrations in leaves and roots, but with a 
213 more pronounced increase in roots than in leaves. Drought was related with higher root $\mathrm{P}$ 214 concentrations and lower foliar $\mathrm{P}$ concentrations (Figure S1). The increases in the 215 response ratio of root $\mathrm{P}$ concentrations were more accentuated for severe droughts 216 (Figure S2). $\mathrm{N}$ fertilization was associated with higher leaf and even higher root $\mathrm{N}$ 217 concentrations (Figure S1). Higher leaf $P$ concentrations and higher root $N: P$ ratio were 218 also associated to $\mathrm{N}$ fertilization (Figure S1). Similarly, $\mathrm{P}$ fertilization was related with 219 increases in $\mathrm{N}$ and $\mathrm{P}$ concentrations in leaves and roots (Figure S1). The combination of 220 elevated $\mathrm{CO}_{2}$ and $\mathrm{N}$ fertilization was related with an increase of root $\mathrm{N}$ concentration 221 (Figure S1).

The response ratios of $\mathrm{N}$ and $\mathrm{P}$ concentrations in leaves and roots in studies

223 providing data for leaves and roots of the same plants thus show a negative sensitivity of 224 leaf and root $\mathrm{N}$ concentration to elevated $\left[\mathrm{CO}_{2}\right]$ and positive $\mathrm{N}$ sensitivities of $\mathrm{N}$ 225 concentrations in leaves and roots to $\mathrm{N}$ fertilization whereas no differences were observed 226 in the corresponding sensitivities of natural log response ratios of $\mathrm{P}$ (Figure 2).

227 Differential stoichiometry responses among vegetation types

228 Elevated $\left[\mathrm{CO}_{2}\right]$ differentially altered nutrient concentrations in different vegetation types.

229 Decreases in leaf $\mathrm{N}$ concentrations but not in root $\mathrm{N}$ concentrations were observed in 230 grasslands, whereas the opposite pattern was observed in croplands exposed to elevated

$231\left[\mathrm{CO}_{2}\right]$ (Figure 3). Decreases in foliar $\mathrm{N}$ concentrations and, on the contrary, increases in 232 root $\mathrm{N}$ concentrations were observed in temperate forests (Figure 3 ). As also observed 233 when analyzing all vegetation types together, leaf and root $\mathrm{N}$ concentrations increased in 234 temperate forests under $\mathrm{N}$ fertilization (Figure 3). However, we had not sufficient data to 235 analyze boreal and tropical ecosystems separately. 
236 Studies providing data for leaves and/or roots but not of the same plants also 237 reported that elevated $\left[\mathrm{CO}_{2}\right]$ and drought were associated with different changes 238 depending on vegetation type. Under elevated $\left[\mathrm{CO}_{2}\right]$, decreases in the leaf $\mathrm{N}$ 239 concentrations were observed in the three vegetation types studied (temperate forests, 240 temperate grasslands and crops) (Figure S3), whereas decreases in root $\mathrm{N}$ concentrations 241 were observed only in temperate forests (Figure S3).

242 Drought was associated with increases in foliar $\mathrm{N}$ concentrations in temperate 243 grasslands and decreases of foliar $\mathrm{P}$ concentration in temperate forest, and with increases 244 in root $\mathrm{N}$ and $\mathrm{P}$ concentrations in crops (Figure S3). All studied vegetation types showed 245 increases in foliar and root $\mathrm{N}$ concentrations associated with $\mathrm{N}$ fertilization (except root $\mathrm{N}$ 246 concentrations in tropical forests) (Figure S3). $\mathrm{N}$ fertilization was also associated to an 247 increase in response ratio of $P$ leaves concentrations in temperate grasslands (Figure S3).

248 A sensitivity analysis of these heterogeneous data confirmed the positive 249 relationships between drought and $\mathrm{N}$ and $\mathrm{P}$ concentrations in roots and the negative 250 relationships between drought with $\mathrm{N}$ and $\mathrm{P}$ concentrations in leaves (Fig. S4). As a result, 251 the $\mathrm{N}: \mathrm{P}$ ratios in roots presented positive responses to elevated $\left[\mathrm{CO}_{2}\right]$, whereas the $\mathrm{N}: \mathrm{P}$ 252 ratio in leaves presented negative responses (Fig S4). 


\section{Discussion}

256 The changes in $\mathrm{N}$ and $\mathrm{P}$ concentrations and $\mathrm{N}: \mathrm{P}$ ratios in response to the drivers studied 257 were mostly similar in leaves and roots, but in some cases and vegetation types were of 258 different magnitudes and even of different directions. Our results confirmed previous 259 studies (Deng et al., 2015; Peñuelas \& Matamala, 1990) that reported a dilution effect 260 under elevated $\left[\mathrm{CO}_{2}\right]$, with lower leaf and root $\mathrm{N}$ concentrations. Moreover, elevated $\left[\mathrm{CO}_{2}\right]$ 261 was associated with changes in $\mathrm{N}$ but not in $\mathrm{P}$ concentrations. The decreases in leaf and 262 root $\mathrm{N}$ concentrations were not accompanied by significant decreases in $\mathrm{P}$ leaf and root 263 concentrations in response to elevated $\left[\mathrm{CO}_{2}\right]$ observing a decrease in roots $\mathrm{N}: \mathrm{P}$ ratio. 264 Deng et al. (2015) also showed that $\mathrm{CO}_{2}$ enhancement had no effect on $\mathrm{P}$ concentrations 265 in plant tissues, when analyzing data coming only from FACE experiments. These results 266 suggest that increased plant biomass under elevated $\left[\mathrm{CO}_{2}\right]$ can be achieved with a more 267 efficient use of $\mathrm{N}$ (consistent with a faster turnover of $\mathrm{N}$-rich Rubisco enzymes to fix more 268 carbon), but not of $\mathrm{P}$, resulting in lower tissue $\mathrm{N}: \mathrm{P}$ ratios. These lower $\mathrm{N}: \mathrm{P}$ ratios, 269 especially when both nutrients are not limiting, are thus associated with the higher growth 270 rates observed under elevated $\left[\mathrm{CO}_{2}\right]$, consistent with the growth rate hypothesis (Sterner \& 271 Elser, 2002). Faster growth would be associated with lower N:P ratios due to the need for 272 more P-rich RNA to sustain rapid protein synthesis (Sterner \& Elser, 2002). Moreover, elevated $\left[\mathrm{CO}_{2}\right]$ in temperate forests decreased foliar $\mathrm{N}$ concentration but 274 not root $\mathrm{N}$ concentration. In contrast, in temperate grasslands, tundra and crops $\mathrm{N}$ 275 concentration changes under elevated $\left[\mathrm{CO}_{2}\right]$ were not different between leaves and roots. 276 This shows that the impacts of global change drivers are different depending on vegetation 277 types and biomes. In this case, the results suggested that the root nutrient concentrations 278 in trees are more responsive than those of grasslands or crops. More $\mathrm{N}$ is thus allocated to 
279

roots of trees under elevated $\left[\mathrm{CO}_{2}\right]$ suggesting a tree investment in the uptake of more soil resources.

Higher $\mathrm{N}$ inputs were associated with a general increase in $\mathrm{N}$ concentrations and $\mathrm{N}: \mathrm{P}$ ratios in leaves and roots. Higher $\mathrm{N}$ inputs may thus increase the uptake of $\mathrm{N}$ but can decrease $\mathrm{P}$ concentration in roots but not in leaves. Leaf $\mathrm{N}$ concentration increased in all studied vegetation types by $\mathrm{N}$ fertilization, whereas leaf $\mathrm{P}$ concentrations increased in response to $\mathrm{N}$ fertilization depending on the vegetation types. Higher foliar $\mathrm{N}$ and $\mathrm{P}$ concentrations may be associated with larger C-assimilation and growth-rate capacities (Sterner \& Elser 2002; Bandau et al., 2015). Increases in $\mathrm{N}$ availability at short to medium terms (months to a few years, depending on input rate) enhance the capacity of plants to take up other nutrients such as P (Coblentz et al., 2004; Zhang et al., 2004; Silva et al., 2015). Long-term N inputs, however, may eventually decrease growth by causing soilplant nutrient imbalances (Jonard et al., 2015; Kou et al., 2015), which can in turn decrease foliar $\mathrm{P}$ concentrations (Wang et al., 2015). However, when increasing atmospheric $\left[\mathrm{CO}_{2}\right]$ coincides with $\mathrm{N}$ fertilization higher allocation of $\mathrm{N}$ and $\mathrm{P}$ to roots is observed suggesting that the lack of $\mathrm{P}$ drives the allocation of $\mathrm{N}$ mainly to roots to increase the uptake capacity of soil resources. Thus, at the root level, there was a compensatory effect on the response ratio of $\mathrm{N}$ and $\mathrm{P}$ concentrations when increasing atmospheric $\left[\mathrm{CO}_{2}\right]$ were combined with higher $\mathrm{N}$ availability. The $\mathrm{N}$-dilution effect frequently observed under increasing atmospheric $\left[\mathrm{CO}_{2}\right]$ is thus logically counteracted by the higher nutrient availability in those combined experiments. However, leaves responded differently than roots. Despite the increased $\mathrm{N}$ availability, concentrations of $\mathrm{N}$ increased only in roots and still declined in the leaves (Fig. 1).

The observed differences between $\mathrm{N}$ concentrations in leaves and in roots under $\mathrm{N}$ fertilization and increasing atmospheric $\left[\mathrm{CO}_{2}\right]$ should be embedded into models of $\mathrm{N}$ and $\mathrm{P}$ 
304 cycles for projecting future scenarios of increasing atmospheric $\left[\mathrm{CO}_{2}\right]$, climate change and $305 \mathrm{~N}$ deposition and they are likely to affect above- and belowground food webs differently. $\mathrm{P}$ enrichment is less widespread than $\mathrm{N}$ enrichment in natural terrestrial 307 ecosystems (Peñuelas et al., 2013; Wang et al., 2015), but P enrichment does 308 nonetheless occur in specific ecosystems, such as wetlands (Osborne et al., 2014), 309 especially near intensively fertilized agricultural lands or near urban areas (Chen et al., 310 2014; Yan et al., 2016). $\mathrm{P}$ fertilization experiments showed increased foliar and root $\mathrm{P}$ 311 concentrations, but also higher foliar and root $\mathrm{N}$ concentrations. These results are 312 consistent with the fact that most studies have observed increased N-uptake capacity due 313 to increases in P availability (Scheiner et al., 2002; Graciano et al., 2006), despite some 314 studies that did not observe this pattern (Graciano et al., 2006). P fertilization can improve $315 \mathrm{~N}$ uptake in different ways. Firstly, $\mathrm{P}$ fertilization can increase soil $\mathrm{N}$ availability (Reed et 316 al., 2007), by increasing the activity of free living $\mathrm{N}_{2}$-fixing soil microbes (Reed et al., 2007; 317 Alguacil et al., 2010) and epiphytic lichens (Abbasi et al., 2008) and increasing plant 318 nodulation in $\mathrm{N}_{2}$-fixing plants (Alguacil et al., 2010; Djumaeva et al., 2013; Benner \& 319 Vitousek, 2007). The increase in $\mathrm{P}$ availability, though, can also increase plant $\mathrm{N}$ content 320 by enhancing $\mathrm{N}$-uptake capacity from increases in the density (Sheng et al., 2012) and 321 length (Sheng et al., 2012; Fageria et al., 2014) of fine roots or by improving the efficiency 322 of $\mathrm{N}$ resorption (Wienend \& Stock, 1995; Ruiz \& Romero, 2000). The increases in N 323 concentrations associated with $\mathrm{P}$ fertilization can have great consequences in nutrient 324 limited ecosystems where plants have a low investment in reproduction that is strongly 325 related to plant nutrient concentrations (Fujita et al., 2010).

Under drought $\mathrm{P}$ concentrations increased in roots but not in leaves. This result is 327 consistent with previous experiments showing that plants under drought reallocate more 328 resources from growth and energy metabolism, including the allocation of $\mathrm{N}$ and $\mathrm{P}$ and 
329 other nutrients towards roots for increasing water uptake (Gargallo-Garriga et al., 2014, 330 2015). Changes in $P$ concentrations were thus observed in roots but not in leaves when 331 plants suffered from drought. Increases in root $\mathrm{N}$ concentration and decreases in foliar $\mathrm{N}$ 332 concentration occurred when increasing atmospheric $\left[\mathrm{CO}_{2}\right]$ coincided with $\mathrm{N}$ fertilization 333 All these different responses in roots than in leaves will likely have different ecological 334 consequences on above- and belowground processes. For example, they could imply a 335 different impact on root-based relative to leaf-based food webs. Changes in plant-host 336 stoichiometry affect the stoichiometry (Kay et al., 2003; Abbas et al., 2004) and growth and 337 survival (Audusseau et al., 2015) of herbivorous insects. Different changes in foliar and 338 root $\mathrm{N}$ and $\mathrm{P}$ concentrations can also affect the respective resorption processes differently 339 and thus above- versus belowground food webs (Sterner \& Elser, 2002). Similarly, other 340 important ecosystemic processes such as the decomposition of organic matter, food fluxes 341 and generally all nutrient and $\mathrm{C}$ cycles can also be affected by changes in $\mathrm{N}$ and $\mathrm{P}$ 342 concentrations and N:P ratios (Schade et al., 2003; Grover, 2003; Cleveland, 2006; Jonas 343 \& Joern, 2008; Sardans et al., 2012b). Some studies of terrestrial ecosystems show that 344 higher $\mathrm{N}$ availability increases body $\mathrm{N}: \mathrm{P}$ ratios and reduces the species diversity of 345 communities, whereas increases in P availability have opposite effects on food resources, 346 with lower N:P ratios increasing the transfer of energy to higher food levels, further 347 favoring larger food webs (Sardans et al., 2012b). All these shifts in the elemental 348 composition of plant organs can thus have important flow-on effects on food webs and 349 ecosystemic structure that could be asymmetrical between above- and belowground 350 ecosystemic compartments in some cases and some ecosystem types by the influence 351 that plant above- and below-ground elemental composition exert on the own food web but 352 also with the food web of the other respective plant compartment (Peñuelas \& Matamala 353 1990, Sterner \& Elser, 2002). Johnson et al. (2013) observed that the relationships 354 between belowground herbivores and root plant nutrient contents also affect aboveground 
355 herbivores and ultimately populations of parasites and predators of aboveground 356 herbivores. A global data synthesis showed that the $\mathrm{C}: \mathrm{N}: \mathrm{P}$ ratios of leaves and roots and 357 the respective above- and below-ground food webs are interconnected (Mulder et al., 358 2013).

We conclude that increasing atmospheric $\left[\mathrm{CO}_{2}\right], \mathrm{N}$ and $\mathrm{P}$ fertilization and drought typically affect the concentrations of $\mathrm{N}$ and $\mathrm{P}$ in leaves and roots similarly, but in some 361 cases they affect them differently or even oppositely, such as when increasing 362 atmospheric $\left[\mathrm{CO}_{2}\right]$ is combined with $\mathrm{N}$ fertilization. The overall analyses of the changes in $363 \mathrm{~N}$ and $\mathrm{P}$ concentrations in leaves and roots in response to the studied global change 364 drivers and their combinations suggested that an equilibrium of the concentration effect (in 365 the case of drought or $\mathrm{N}$ and $\mathrm{P}$ fertilization) and the dilution effect (in the case of elevated $366\left[\mathrm{CO}_{2}\right]$ ) with the increasing $\mathrm{N}$ and $\mathrm{P}$ allocation to roots to enhance the uptake of other soil 367 resources when $\mathrm{N}$ and/or $\mathrm{P}$ availability increased. Then the results suggest that when 368 several different resources are provided at once enhancing the potential for plant 369 production capacity, more sources are allocated to roots to improve the uptake of 370 complementary resources to those enhanced by environmental changes. This occurs for $\mathrm{N}$ 371 and $\mathrm{P}$ under drought, for $\mathrm{N}$ under $\mathrm{N}$ fertilization, for $\mathrm{P}$ under $\mathrm{P}$ fertilization, for $\mathrm{N}$ and $\mathrm{P}$ 372 under $\mathrm{N}$ and $\mathrm{P}$ fertilization and for $\mathrm{N}$ when $\mathrm{N}$ and $\mathrm{CO}_{2}$ increase. This is not observed under 373 elevated $\mathrm{CO}_{2}$. The dilution effect together with the necessity to maintain $\mathrm{N}$ in 374 photosynthetic tissues to take profit of higher $\mathrm{CO}_{2}$ could explain it. The results also 375 suggest that above- and belowground processes could sometimes be affected differently 376 and even oppositely by the drivers of Global Change. Such differential shifts in above377 versus below-ground elemental composition can change ecosystem function, for example 378 by affecting the corresponding food webs differently. Furthermore, several models of 379 carbon cycles in terrestrial ecosystems have been developed to determine the 
mechanisms behind the shoot/root allocation of carbon (Wilson, 1988; Cannell \& Dewar, 1994). The results suggest the need to also incorporate flexible allocations of $N$ and $P$ concentrations to different plant organs in the distinct biomes into models projecting effects under different scenarios of climate and fertility.

\section{Acknowledgements}

The authors would like to acknowledge the financial support from the European Research Council Synergy grant ERC-SyG-2013-610028 IMBALANCE-P, the Spanish Government grant CGL201348074-P and the Catalan Government grant SGR 2014-274.

\section{References}

Abbas M, Klein AM, Ebeling A, Oelmann Y, Ptanick R, Weisserg WW, Hillebrand H (2014) Plant diversity effects on pollinating and herbivorous insects can be linked to plant stoichiometry. Basic Applied Ecology, 15, 169-178.

Abbasi MK, Majeed A, Sadiq A, Khan SR (2008) Application of Bradyrhizobium japonicum and phosphorus fertilization improved growth, yield and nodulation of soybean in the sub-humid hilly region of Azad Jammu and Kashmir, Pakistan. Plant Production Science, 11, 368-376.

Akmal M, Schelberg J, Khattak RA (2010) Biomass allocation and nitrogen distribution in ryegrass under water and nitrogen supplies. Journal of Plant Nutrition, 35, 17771788.

Alguacil MD, Lozano Z, Campoy MJ, Roldan (2010) A Phosphorus fertilization management modifies the biodiversity of AM fungi in a tropical savanna forage system. Soil Biology and Biochemistry, 42, 1114-1122.

Audusseau H, Kolb G, Janz N (2015) Plant fertilization interacts with life history: variation in stoichiometry and performance in Nettle-Feeding butterflies. Plos One, 10, e0124616.

Bandau F, Decker VHG, Gundale MJ, Albrectsen BR (2015) Genotypic tannin levels in Populus tremula impact the way nitrogen enrichment affects growth and allocation responses for some traits and not for others. PlosOne, 10, e0140971.

Benner JW, Vitousek PM (2007) Development of a diverse epiphyte community in response to phosphorus fertilization. Ecology Letters, 10, 628-636.

Chen FS, Yavitt J, Hu XF (2014) Phosphorus enrichment helps increase soil carbon mineralization in vegetation along an urban-to-rural gradient, Nanchang, China. Applied Soil Ecology, 75, 181-188.

Churkina G, Brovkin V, von Bloh W, Trusilova K, Jung M, Dentener F (2009) Synergy of rising nitrogen depositions and atmospheric $\mathrm{CO}_{2}$ on land carbon uptake moderately offsets global warming. Global Biogeochemical Cycles, 23, GB4027.

Cleveland CC, Reed SC, Townsend AR (2006) Nutrient regulation of organic matter decomposition in a tropical rain forest. Ecology, 87, 492-503. 
420

421

422

423

424

425

426

427

428

429

430

431

432

433

434

435

436

437

438

439

440

441

442

443

444

445

446

447

448

449

450

451

452

453

454

455

456

457

458

459

460

461

462

463

464

465

466

467

468

469

470

Coblentz WK, Daniels MB, Gunsaulis JL et al. (2004) Effects of nitrogen fertilization on phosphorus uptake in Bermudagrass forage grown on high soil-test phosphorus sites. Profesional Animal Science, 20, 146-154.

Crous JW, Morris AR, Scholes MC. (2011) Changes in topsoil, standing litter and tree nutrient content of a Pinus patula plantation after phosphorus and potassium fertilization. European Journal of Forest Research, 130, 277-292.

Deng Q, Hui D, Luo Y, Elser JJ, Wang YP, Loladze I, Zhang Q, Dennis S (2015) Downregulation of tissue $\mathrm{N}: \mathrm{P}$ ratios in terrestrial plants by elevated $\mathrm{CO}_{2}$. Ecology, 96, 3354-3362.

Dieleman WIJ, Vicca S, Dijkstra FA et al. (2012) Simple additive effects are rare: a quantitative review of plant biomass and soil process responses to combined manipulations of $\mathrm{CO}_{2}$ and temperature. Global Change Biology, 18, 2681-2693.

Djumaeva D, Lamers JPA, Khamzina A, Vlek PL (2013) The benefits of phosphorus fertilization of trees grown on salinized croplands in the lower reaches of Amu Darya, Uzbekistan. Agroforestry Systems, 87, 555-569.

Duval BD, Blankinship Djikstra P, Hungate BA (2012) $\mathrm{CO}_{2}$ effects on plant nutrient concentration depend on plant functional group and available nitrogen: a metaanalysis. Plant Ecology, 213, 505-521.

Fageria NK, Moreira A, Moraes LAC, Moraes MF (2014) Root growth, Nutrient uptake, and Nutrient-use-efficiency by roots of tropical legume cover crops as influenced by phosphorus fertilization. Commun. Soil Science and Plant Analysis, 45, 555-569.

Fujita Y, Olde Venterink H, van Bodegom PM et al. (2010) Low investment in sexual reproduction threatens plants adapted to phosphorus limitation. Nature, 505, 82-86.

Gargallo-Garriga A, Sardans J, Pérez-Trujillo M et al., (2014) Opposite metabolic responses of shoots and roots to drought. Scientific Reports, 4, 6829.

Gargallo-Garriga A, Sardans J, Ovarec M et al. (2015) Warming differently influences the effects of drought on Stoichiometry and metabolomics in shoots and roots. New Phytologist, 207, 591-603.

Graciano C, Goya JF, Frangi JL, Guiamet JJ (2006) Fertilization with phosphorus increases soil nitrogen absorption in Young plants of Eucalyptus grandis. Forest Ecology and Management, 236, 202-210.

Grover P (2003). The impact of variable stoichiometry on predator-prey interactions: a multinutrient approach. American Naturalist 162, 29-43

Hedges LV, Gurevitch J. Curtis PS (1999) The meta-analysis of response ratios in experimental ecology. Ecology, 80, 1150-1156.

Jonard M, Fuerst A, Verstraeten A et al. (2015) Tree mineral nutrition is deteriorating in Europe. Global Change Biology, 21, 418-430

Jonas JL, Joern A (2008) Host-plant quality alters grass/forb consumption by a mixedfeeding insect herbivore, Melanoplus bivittatus (Orthrptera: Acrididae). Ecologial Entomology, 33, 546-554.

Johnson SN, Mitchell C, McNicol JW, Thompson J, Karley AJ (2013) Downstairs droversroot herbivores shape communities of above-ground herbivores and natural enemies via changes in plant nutrients. Journal of Animal Ecology, 82, 1021-1030.

Kay A, Schade J, Novotny A, Hernández D, Ogdahl M, Sterner RW, Hobbie, SE (2003) Body size and N:P stoichiometry of insect herbivores vary with host plant chemistry. Ecological Society American Annual Meeting Abstracts, 88,176.

Kerkhoff AJ, Enquist BJ, Elser JJ, Fagan WF (2005) Plant allometry, stoichiometry and the temperature-dependence of primary productivity. Global Ecology and Biogeography, 14, 585-598.

Kerkhoff AJ, Enquist BJ (2006) Ecosystem allometry: the scaling of nutrient stocks and primary productivity across plant communities. Ecology Letters, 9, 419-427. 
471

472

473

474

475

476

477

478

479

480

481

482

483

484

485

486

487

488

489

490

491

492

493

494

495

496

497

498

499

500

501

502

503

504

505

506

507

508

509

510

511

512

513

514

515

516

517

518

519

Kou L, Guo DL, Yang H, Gao WL, Li SG (2015) Growth, morphological traits and mycorrhizal colonization of fine roots respond differently to nitrogen addition in a slash pine plantation in subtropical China. Plant Soil, 391, 207-218.

Leuzinger S, Luo Y, Beier C, Dieleman W, Vicca V, Körner CD (2011) global change experiments overstimatre impacts on terrestrial ecosystems? Trends in Ecology and Evolution, 26, 236-241.

Li J, Zhou JM, Duan ZQ, Du CW, Wang HY (2007) Effect of $\mathrm{CO}_{2}$ enrichment on the growth and nutrient uptake of tomato seedlings. Pedosphere, 17, 343-351.

Liu XJ, Zhang Y, Han WX, Tang AH, Shen JL, Cui ZL, Vitousek P, Erisman JW, Goulding $\mathrm{K}$, et al. (2013) Enhanced nitrogen deposition over China. Nature, 494, 459-462.

Liu J, Huang W, Zhou G, Zhang D, Liu S, Li Y (2013) Nitrogen to phosphorus ratios of three species response to elevated carbon dioxide and nitrogen addition in subtropical forests. Global Change Biology, 19, 208-216.

Meyerholds J, Zaehle S (2015) The role of stoichiometry flexibility in modelling forest ecosystem responses to nitrogen fertilization. New Phytologist, 208, 1042-1055.

Mulder C, Ahrestani FS, Bahn M et al. (2013) Connecting the green and brown worlds: allometric and stoichiometric predictability of above- and below-ground networks. Advances in Ecology Research, 49, 69-175.

Osborne TZ, Reddy KR, Ellis LR, Aumen NG, Surratt DD, Zimmerman MS, Sadle J (2014) Evidence of recent phosphorus enrichment in surface soils of Taylor slough and Northeast everglades National Park. Wetlands, 34, S37-S45.

Peñuelas J, Poulter B, Sardans J et al., (2013) Human-induced nitrogen-phosphorus imbalances alter natural and managed ecosystems across the globe. Nature Communications, 42934, 1-10

Peñuelas J, Matamala R (1990) Changes in N and S leaf content, stomatal density and specific leaf area of 14 plant species during the last three centuries of $\mathrm{CO}_{2}$ increase. Journal of Experimental Botany, 41, 1119-1124.

R Core Team (2015) R: A language and environment for statistical computing. R Foundation for Statistical Computing, Vienna, Austria. URL https://www.Rproject.org/..

Reed SC, Seastedt TR, Mann CM, Suding KN, Townsend AR, Cherwin KL (2007) Phosphorus fertilization stimulates nitrogen fixation and increases inorganic nitrogen concentrations in a restored prairie. Applied Soil Ecology, 36, 238-242.

Reich PB, Hobbie SE (2012) Decade-long soil nitrogen constraint on the $\mathrm{CO}_{2}$ fertilization of plant biomass. Nature Climate Change, 3, 278-282.

Ruiz JM, Romero L (2000) Nitrogen metabolism and yield response of cucumber (Cucumis sativus L cv Brunex) plants to phosphorus fertilization. Journal of Science Food Agriculture, 80, 2069-2073.

Sardans J, Peñuelas $\mathrm{J}$ (2012) The role of plants in the effects of global change on Nutrient availability and nutrient stoichiometry in the Plant-Soil system. Plant Physiology, 160, 1741-1761.

Sardans J, Peñuelas J, Ogaya R (2008) Drought induced changes in C and N stoichiometry in a Quercus ilex Mediterranean Forest. Forest Science, 54, 513-522.

Sardans J, Peñuelas J, Prieto P, Estiarte M (2008) Drought and warming induced changes in $\mathrm{P}$ and $\mathrm{K}$ concentration and accumulation in plant biomass and soil in a Mediterranean shrubland. Plant Soil, 306, 261-271.

Sardans J, Rivas-Ubach A, Peñuelas J (2012b) The C:N:P Stoichiometry of organisms and Ecosystems in a changing world: A review and perspectives. Perspectives in Plant Ecology, Evolution and Systematics, 14, 33-47. 
Sardans J, Bartrons M, Margalef O. et al. (2017) Plant Invasion is associated with higher plant-soil nutrient concentrations in nutrient-poor environments. Global Change Biology 23, 1282-1291.

Schade JD, Kyle M, Hobbie SE, Fagan WF, Elser JJ (2003) Stoichiometric tracking of soil nutrients by a desert insect herbivoere. Ecological Letters, 6, 96-101.

Scheiner JD, Gutierrez-Boem FH, Lavado RS (2002) Sunflower nitrogen requirement and ${ }^{15} \mathrm{~N}$ fertilizer recovery in western Pampas, Argentina. European Journal of Agronomy, 17, 73-79.

Sheng M, Lalande R, Hamel C, Ziadi N, Shi YC (2012) Growth of corn roots and associated arbuscular mycorrhizae are affected by long-term tillage and phosphorus fertilization. Agronomy Journal, 104, 1672-1678.

Silva LCR, Gomez-Guerrero A, Doane T, Howarth WR (2015) Isotopic and nutrititional evidence for species- and site-specific responses to $\mathrm{N}$ deposition and elevated $\mathrm{CO}_{2}$ in temperate forests. Journal of Geophysical Research Biogeosciences, 120, 11101123.

Sterner RW, Elser JJ (2002) Ecological Stoichiometry: The Biology of Elements from Molecules to the Biosphere. Princenton University Press.

Thomas RQ, Bonan GB, Goodale CL (2013) Insights into mechanisms governing forest carbon response to nitrogen deposition: a model-data comparison using observed responses to nitrogen addition. Biogeosciences, 10, 3869-3887.

Van der Velde M, Folberth C, Balkovic J et al., (2014) African crop yield reductions due to increasingly unbalanced nitrogen and phosphorus consumption. Global Change Biology, 20, 1278-1288.

Viechtbauer WR (2012) package: Metafor. Available at website http://

www.metafor-project.org/doku.php.

Wang R, Balkanski Y, Boucher O, Ciais P, Peñuelas J, Tao S (2015) Significant contribution of combustion-related emissions to the atmospheric phosphorus budget. Nature Geosciences, 8, 48-54.

Wienend KT, Stock WD (1995) Long-term phosphorus fertilization effects on the litter dynamics of an age sequence of Pinus-elliottii plantations in the Southern Cape of South-Africa. Forest Ecology Management, 75, 135-146

Wilson JB (1988) Shoot Competition and Root Competition. J. Appl. Ecol. 25, 279-296.

Cannell MGR, Dewar RC (1994) Carbon Allocation in Trees: a Review of Concepts for Modelling. Advances in Ecological Research, 25, 59-104.

Yan Z, Han W, Peñuelas J, Sardans J, Elser JJ, Du E, Reich PB, Fang J (2016) Phospsorus accumulates faster than nitrogen globally in freshwater ecosystems under anthropogenic impacts. Ecology Letters, 19, 1237-1246.

Yuan ZY, Chen HYH (2015) Decoupling of nitrogen and phosphorus in terrestrial plants associated with global changes. Nature Climate Change, 5, 465-469.

Zhang F, Kang S, Zhang J, Zhang R, Li F (2004) Nitrogen fertilization on uptake of soil inorganic phosphorus fractions in the wheat root zone. Soil Science Society American Journal, 68, 1890-1895.

\section{Additional information}

Supplementary information for only on-line publication is added 


\section{Competing interests}

570 The authors declare no competing financial interests.

571

572 Table 1. Summary of the results of the meta-analyses for the concentrations of $\mathrm{N}$ and $\mathrm{P}$ 573 and the corresponding ratios in response to the Global-Change drivers.

\begin{tabular}{|l|c|c|c|c|}
\hline \multirow{2}{*}{$\begin{array}{l}\text { Global-Change } \\
\text { driver }\end{array}$} & \multicolumn{2}{|c|}{$[\mathrm{N}]$} & \multicolumn{2}{c|}{$[\mathrm{P}]$} \\
\cline { 2 - 5 } Elevated $\left[\mathrm{CO}_{2}\right]$ & Leaves & \multicolumn{1}{|c|}{ Roots } & Leaves & Roots \\
\hline $\mathrm{N}$ fertilization & $\uparrow$ & $\uparrow$ & $\uparrow$ & $\downarrow$ \\
\hline P fertilization & $\mathrm{NA}$ & $\mathrm{NA}$ & $\uparrow$ & $\uparrow$ \\
\hline Drought & $\uparrow$ & $\uparrow$ & $=$ & $\uparrow$ \\
\hline $\begin{array}{l}{\left[\mathrm{CO}_{2}\right]+} \\
\text { fertilization }\end{array}$ & $\downarrow$ & $\uparrow^{\mathrm{a}}$ & $=$ & $\uparrow$ \\
\hline $\begin{array}{l}\mathrm{N}+ \\
\text { fertilization }\end{array}$ & $\uparrow$ & $\uparrow$ & $\uparrow$ & $\uparrow$ \\
\hline
\end{tabular}

$574 \uparrow$, significant $(P<0.05)$ increases in meta-analysis; $\downarrow$, significant decreases $(P<0.05)$ in 575 meta-analysis; =, no change in meta-analysis; NA, not available. Different letters indicate 576 significant differences $(P<0.05)$ in response ratios between leaves and roots. Different 577 letters indicate significant differences $(P<0.05)$ in response ratios between photosynthetic 578 tissues and roots only when overall data was analyzed including studies with data of leaf 579 and/or roots.

580

581

582

583

584

585 
Figure Captions

Figure 1. Natural log response ratios of $N$ and $P$ concentrations and $N: P$ ratios in leaves (blue) and roots (grey) due to elevated $\left[\mathrm{CO}_{2}\right]$, drought, $\mathrm{N}$ fertilization, $\mathrm{P}$ fertilization, elevated $\left[\mathrm{CO}_{2}\right]+\mathrm{N}$ enrichment, $\mathrm{N}+\mathrm{P}$ enrichment and elevated $\left[\mathrm{CO}_{2}\right]+$ drought. The meta-analyses were conducted only with studies that provided data of leaves and roots measured simultaneously in the same plants. Error bars indicate the mean response ratio with $95 \%$ confidence intervals. The numbers between brackets indicate the number of reports and observations, respectively, used in the meta-analysis of each variable. $\left(^{* * *}\right)$, $\left({ }^{* *}\right)$, and $\left({ }^{*}\right)$ indicate significant differences at $(P<0.001), \quad(P<0.01)$ and $(P<0.05)$ respectively, between treated plants compared with the control plants. Positive response ratios mean that the corresponding global change drivers increased the value of the variable with respect to the control conditions.

Figure 2. Sensitivity of the natural log response ratios of $N$ and $P$ concentrations (by ppm of elevated $\left[\mathrm{CO}_{2}\right]$ ) in leaves and roots to elevated $\left[\mathrm{CO}_{2}\right]$ and sensitivity of the natural log response ratios of $\mathrm{N}$ and $\mathrm{P}$ concentrations (by kg ha ${ }^{-1}$ of $\mathrm{N}$ enhancement) in leaves and roots to $\mathrm{N}$ fertilization obtained in studies that provided data of leaves and roots of the same plants. Error bars indicate the $95 \%$ confidence intervals for the mean response ratio. The numbers between brackets indicate the number of reports and observations, respectively, used in the meta-analysis of each variable. $\left(^{* * *}\right),\left({ }^{* *}\right)$, and $\left({ }^{*}\right)$ indicate significant differences, at $(P<0.001),(P<0.01)$ and $(P<0.05)$ respectively, between treated plants compared with the control plants. Positive response ratios mean that the corresponding global change drivers increased the value of the variable with respect to the control conditions.

Figure 3. Natural log response ratios due to elevated $\left[\mathrm{CO}_{2}\right]$ and to $\mathrm{N}$ fertilization on $\mathrm{N}$ concentrations in leaves and roots in different vegetation types obtained in studies that provided data of leaves and roots of the same plants. Error bars indicate the 95\% confidence intervals for the mean response ratio. The numbers between brackets indicate the number of reports and observations, respectively, used in the meta-analysis of each variable. $\left({ }^{* * *}\right),\left({ }^{* *}\right)$, and $\left({ }^{*}\right)$ indicate significant differences, at $(P<0.001),(P<0.01)$ and $(P<0.05)$ respectively, between treated plants compared with the control plants. Positive response ratios mean that the corresponding global change drivers increased the value of the variable with respect to the control conditions. 
624

625

626

627 


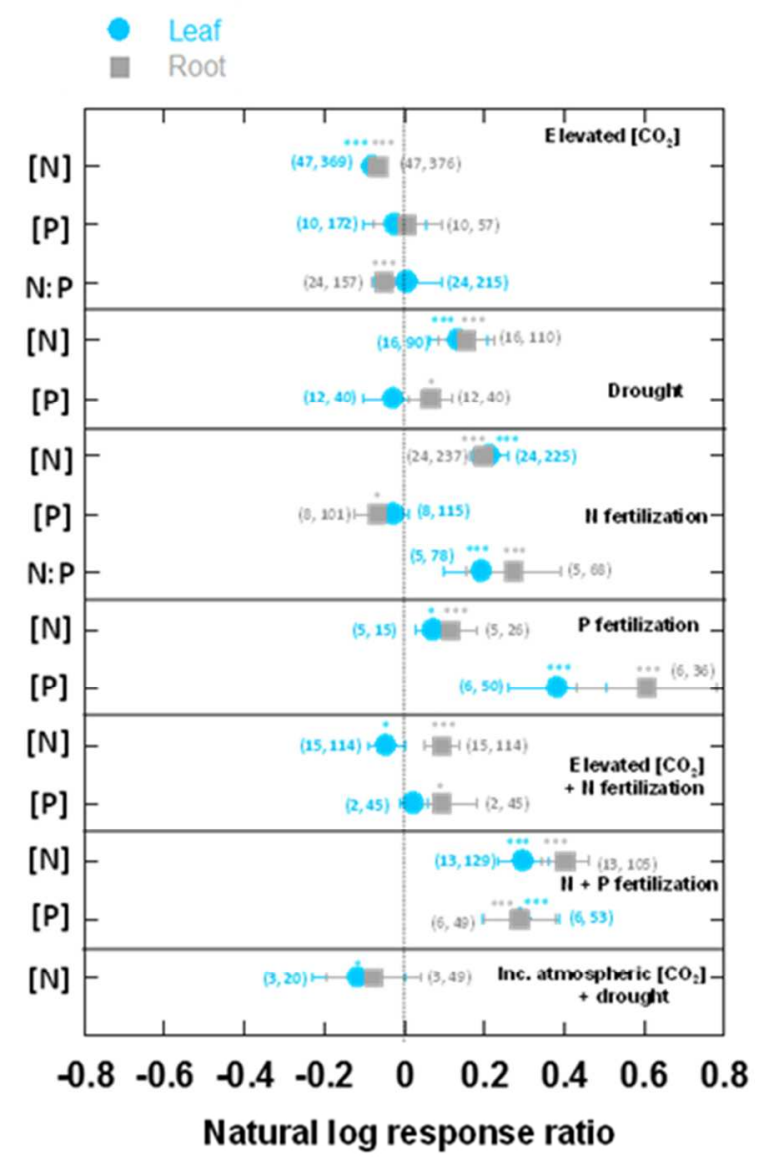

Figure 1. Natural log response ratios of $\mathrm{N}$ and $\mathrm{P}$ concentrations and $\mathrm{N}: \mathrm{P}$ ratios in leaves (blue) and roots (grey) due to elevated [CO2], drought, $\mathrm{N}$ fertilization, $\mathrm{P}$ fertilization, elevated [CO2] $+\mathrm{N}$ enrichment, $\mathrm{N}+\mathrm{P}$ enrichment and elevated [CO2] + drought. The meta-analyses were conducted only with studies that provided data of leaves and roots measured simultaneously in the same plants. Error bars indicate the mean response ratio with $95 \%$ confidence intervals. The numbers between brackets indicate the number of reports and observations, respectively, used in the meta-analysis of each variable. (***), (**), and (*) indicate significant differences at $(P<0.001),(P<0.01)$ and $(P<0.05)$ respectively, between treated plants compared with the control plants. Positive response ratios mean that the corresponding global change drivers increased the value of the variable with respect to the control conditions. 


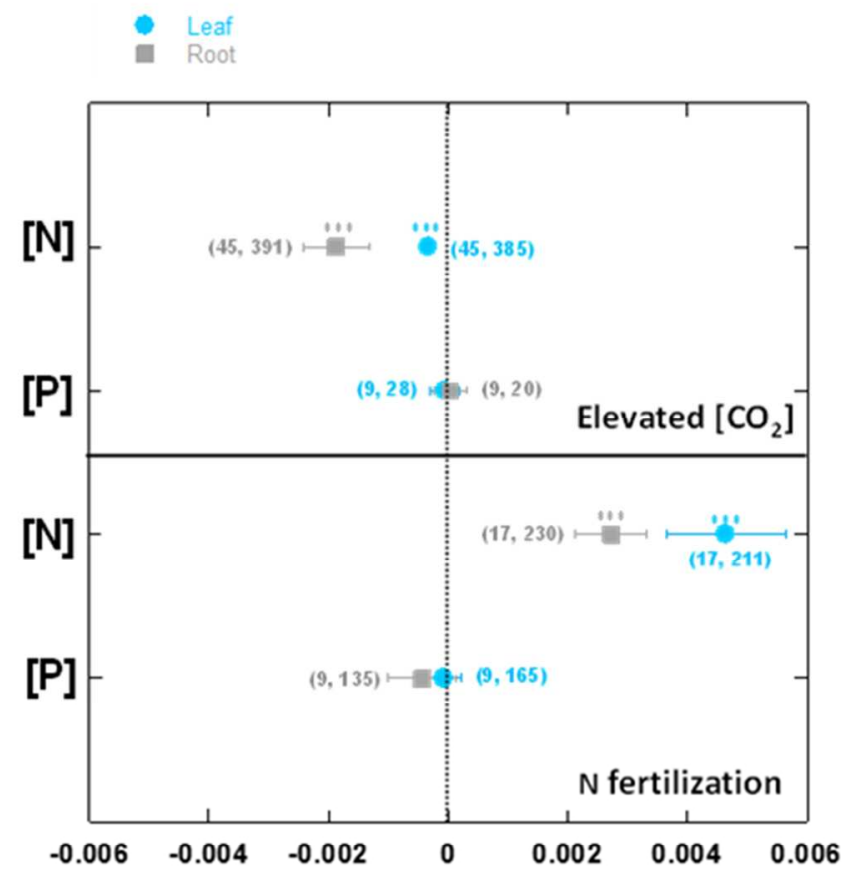

Sensitivity natural log response ratio

Figure 2. Sensitivity of the natural log response ratios of $\mathrm{N}$ and $\mathrm{P}$ concentrations (by ppm of elevated [CO2]) in leaves and roots to elevated [CO2] and sensitivity of the natural log response ratios of $\mathrm{N}$ and $\mathrm{P}$ concentrations (by kg ha- 1 of $\mathrm{N}$ enhancement) in leaves and roots to $\mathrm{N}$ fertilization obtained in studies that provided data of leaves and roots of the same plants. Error bars indicate the $95 \%$ confidence intervals for the mean response ratio. The numbers between brackets indicate the number of reports and observations, respectively, used in the meta-analysis of each variable. $(* * *),(* *)$, and $\left(^{*}\right)$ indicate significant differences, at $(P<0.001),(P<0.01)$ and $(P<0.05)$ respectively, between treated plants compared with the control plants. Positive response ratios mean that the corresponding global change drivers increased the value of the variable with respect to the control conditions. 


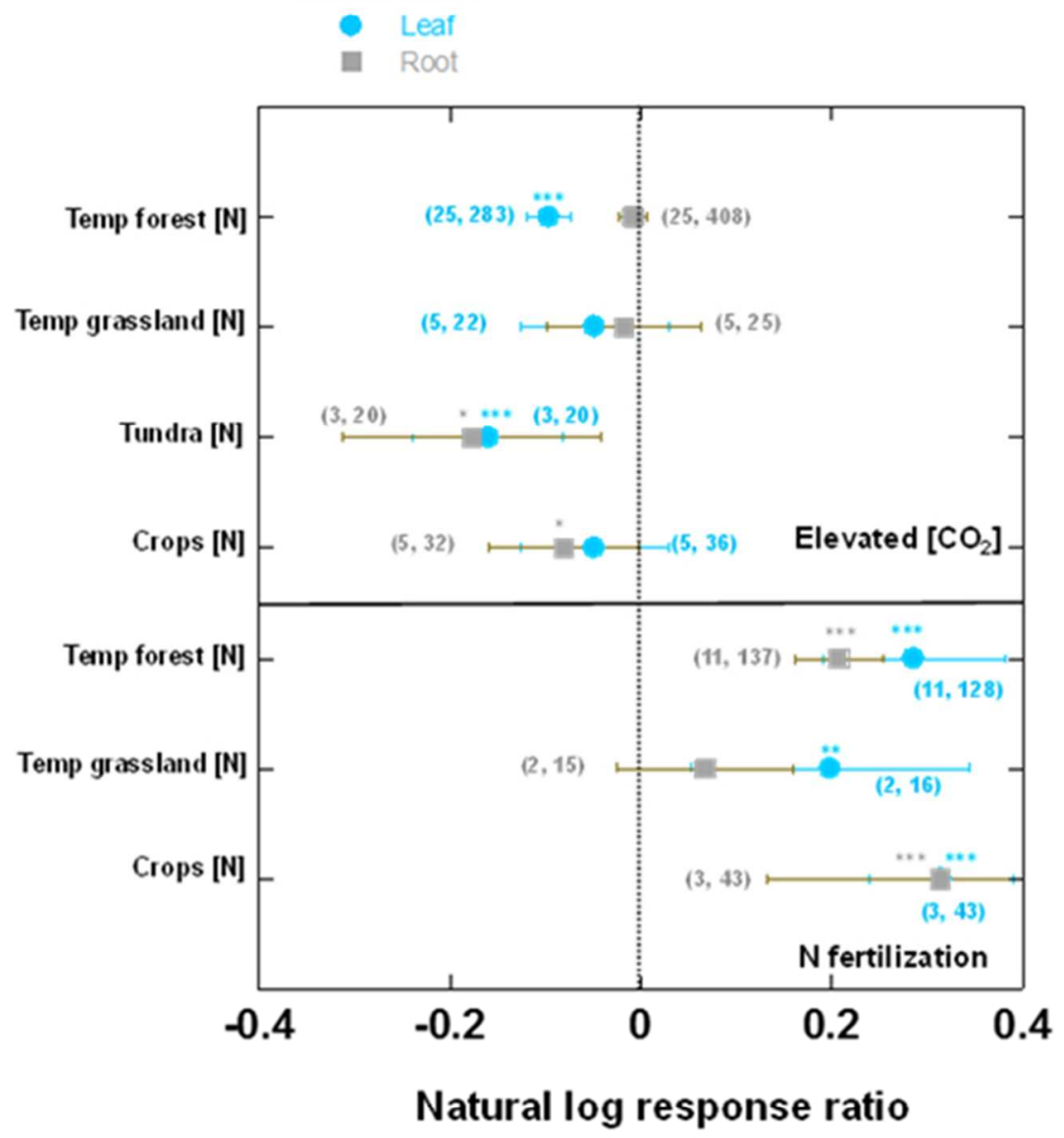

Figure 3. Natural log response ratios due to elevated [CO2] and to $\mathrm{N}$ fertilization on $\mathrm{N}$ concentrations in leaves and roots in different vegetation types obtained in studies that provided data of leaves and roots of the same plants. Error bars indicate the $95 \%$ confidence intervals for the mean response ratio. The numbers between brackets indicate the number of reports and observations, respectively, used in the meta-analysis of each variable. $(* * *),(* *)$, and $(*)$ indicate significant differences, at $(P<0.001),(P<0.01)$ and $(P<0.05)$ respectively, between treated plants compared with the control plants. Positive response ratios mean that the corresponding global change drivers increased the value of the variable with respect to the control conditions. 